\title{
INFLUENCE OF SEMEN QUALITY ON SPERM SURVIVABILITY, SPERM DNA FRAGMENTATION AND FERTILITY RATE OF THE MALE DROMEDARY CAMELS
}

Zeidan, A.E.B.; E.A.A. Ahmadi ; A.M. Amer ; T.M.M. Mahdy and A.L.I. Desoky.

Animal Production Research Institute, Dokki, Giza, Egypt.

Key Words: Dromedary camels, Semen quality, Blood, DNA fragmentation, Conception rate.

\section{ABSTRACT}

Two experiments were carried out. Twelve Maghrebi camels at $<6$ to 10 years of age were used in the present study. Semen samples were collected using an artificial vagina (AV) and divided into their qualities to three groups (Poor $\geq 20-40 \%$ motile spermatozoa, Normal, $\geq 40-60 \%$ motile spermatozoa and Good, $\geq 60-80 \%$ motile spermatozoa). Copulation time, semen characteristics, sperm DNA fragmentation Index, sperm mensuration and blood constituents of the male dromedary camels were recorded (Experiment 1). Different semen qualities were diluted with Lactose-YolkCitrate (LYC) extender and stored at $5^{\circ} \mathrm{C}$ for 3 days (Experiment 2). Conception rates $(\%)$ of she-camels artificially inseminated with different semen qualities were assessed.

The obtained results showed that, copulation time ( $\mathrm{min})$ and semenejaculate volume $(\mathrm{ml})$ were significantly $(\mathrm{P}<0.05)$ better in camels containing Normal and Good quality than Poor quality of semen. Semen colour was Thin creamy, Creamy and Creamy whereas semen consistency was Semi-viscous, Viscous and Viscous for Poor, Normal and Good quality of the dromedary camel semen, respectively. Furthermore, seminal $\mathrm{pH}$ value and sperm mensuration $(\mu \mathrm{m})$ of the dromedary camels were insignificantly differences in different semen qualities. The percentage of sperm motility and sperm-cell concentration $\left(\times 10^{6} / \mathrm{ml}\right)$ were significantly $(\mathrm{P}<0.05)$ increased, while the percentages of dead spermatozoa, abnormal spermatozoa, acrosome damage, sperm chromatin damage and sperm DNA fragmentation Index were significantly $(\mathrm{P}<0.05)$ decreased of the camels with Normal and Good quality than Poor quality of the dromedary camel semen. Moreover, total protein, albumin and globulin $(\mathrm{gm} / 100 \mathrm{ml})$ concentrations showed insignificantly higher, while total cholesterol concentration $(\mathrm{mg} / 100 \mathrm{ml})$ was significantly $(\mathrm{P}<0.05)$ higher in the camels containing Normal and Good quality than Poor quality of semen. On the other hand, Sodium concentration $(\mathrm{mg} / 100 \mathrm{ml})$ and activity of aspartateaminotransaminase (AST) and alanine-aminotransaminase (ALT) enzymes increased significantly $(\mathrm{P}<0.05)$ in the camels having Poor quality compared 
to those with Normal and Good quality of semen. Similarly, Potassium $(\mathrm{mg} / 100 \mathrm{ml})$, Calcium $(\mathrm{mg} / 100)$, Total phosphorus $(\mathrm{mg} / 100 \mathrm{ml})$, Zinc $(\mu \mathrm{g} / 100 \mathrm{ml})$ and testosterone concentrations $(\mathrm{ng} / 100 \mathrm{ml})$ were significantly $(\mathrm{P}<0.05)$ higher in the camels having Normal and Good quality than Poor quality of semen (Experiment 1). The percentages of sperm motility and sperm storagability of the diluted spermatozoa with LYC extender were significantly $(\mathrm{P}<0.05)$ higher in the camels with Normal and Good quality of semen, while the percentages of dead spermatozoa, abnormal spermatozoa, acrosome damage and sperm chromatin damage and activity of AST and ALT enzymes were significantly $(\mathrm{P}<0.05)$ lower in the camels having Normal and Good quality than Poor quality of the camel semen stored at $5^{\circ} \mathrm{C}$ (Experiment 2). The advancement of storage times was decreased significantly $(\mathrm{P}<0.05)$ semen quality in different qualities of semen with the successive storage times at $5^{\circ} \mathrm{C}$ for 3 days. Conception rates $(\%)$ of shecamels artificially inseminated with different qualities were significantly $(\mathrm{P}<0.05)$ lower with Poor quality than Normal and Good quality of semen. In conclusion, copulation time, semen characteristics, sperm mensuration, sperm DNA fragmentation Index, blood constituents, sperm survivability and fertility rates showed better for Normal and Good quality than Poor quality semen.

\section{INTRODUCTION}

The camel (Camelus dromedaius) is an important livestock species that can uniquely adapted to hot and arid environments. There is an urgent need to develop food production resources in Africa and other developing countries to solve the dramatic increasing in human population and insufficient amount of meat and milk.

Maximizing the use of outstanding sires in artificial breeding depends on many factors. Developing and extender that preserves the high fertility of unfrozen semen for a long time would help increase the overall conception rate, encourage more complete use of semen and make semen from outstanding sires more widely available in management systems using fresh semen (Foote and Bratton, 1960).

The blood constituents are the mirror which reflects the healthy condition of animals. So, the biochemical studies under different fluctuating climatic conditions are very important for clinicians in the field during interpretation of their findings. Minerals and trace elements has long been known to be important in animal nutrition as they may be dietary essential and vital to enzyme processes of living cells or have some metabolic activity, bone formation and reproductive performance (Zeidan et al., 2001 and Matter, 2019).

Media known to prolong the survival of fresh bovine spermatozoa contain complex buffers (Foote and Bratton 1960), and varying levels of egg yolk, glucose, glycine, glycerol, citrate and other salts (Foote and 
Bratton 1960). It has long been recognized that the electrolyte composition, buffering agent and osmotic pressure of the solution.

Achievement of the high reproductive activity partially depends on the success of artificial insemination (AI) which in turn is dependent on semen quality obtained and its capacity for dilution and storage with minimum loss of fertilizing ability (Wilson, 1984). Generally, the live spermatozoa can be prolonged for several days at chilled storage $\left(2-5^{\circ} \mathrm{C}\right)$. However, satisfactory fertility results are not always achieved after as little as one day of storage (Murase et al.,1990 and Zeidan et al., 2001).

Semen characteristics were considered inconstant predictors of reproductive efficiency especially with very poor quality (RodriguezMartinez, 2003). Artificial insemination programs is focusing on the development of accurate methods that have been able to predict field fertility with frozen-thawed semen. Indeed, more sensitive methods are needed to enable elimination of the low fertility in the high selected bull (Hallap et al., 2005). Semen quality must consider not only sperm motility and viability but also sperm functional competence like capacitation, sperm chromatin damage and sperm DNA fragmentation Index. Studies in humans indicate that the frequency of spermatozoa containing fragmented DNA may be a new independent parameter of semen quality and fertility (Evenson $\boldsymbol{e t}$ al., 2002). A new procedure for the sperm DNA fragmentation Index has been developed in human sperm (Frenandez et al., 2003) and in mouse (Rodriguez et al., 2005) based on the sperm chromatin damage test (Enciso et al., 2006).

The objective of the present work was to study the effects of copulation time, semen characteristics, sperm mensuration, blood constituents, sperm chromatin damage and sperm DNA fragmentation Index in the different semen qualities of dromedary camels (Experiment 1). Evaluation of different semen qualities and sperm survivability of the diluted camel semen with LYC extender during storage at $5^{\circ} \mathrm{C}$ for 3 days in different qualities of semen was recorded (Experiment 2). Conception rates $(\%)$ of she-camels artificially inseminated with different semen qualities were also assessed.

\section{MATERIALS AND METHODS}

The experimental work was carried out in the Laboratory of Public Health, Faculty of Veterinary Medicine, Zagazig University, Zagazig, and Private Camel Farm, Marsa Motrouh Governorate, Egypt, during the period from December, 2019 to October, 2020.

Two experiments were carried out. The objective of the first experiment was to study the effects of copulation time, semen characteristics, sperm mensuration, blood constituents, sperm chromatin damage and sperm DNA fragmentation Index in different semen qualities in the dromedary camels. After collection, semen was evaluated and the 
ejaculates were diluted with LYC extender could be considered as the Poor quality (consistently $\geq 20-40 \%$ motile spermatozoa, Normal $\geq 40-60 \%$ motile spermatozoa and Good $\geq 60-80 \%$ motile spermatozoa). The second experiment aimed to define the effects of semen quality on survivability and activity of AST and ALT enzymes of the camel spermatozoa diluted with LYC extender during storage at $5^{\circ} \mathrm{C}$ for 3 days. Conception rates $(\%)$ of shecamels artificially inseminated with different semen qualities were recorded.

\section{Materials:}

\subsection{Experimental animals :}

Twelve Maghrebi camels (Camelus dromedarius) aging < 6-10 years old and 500-600 kg live body weight, were used in the present study. All camels were in healthy condition.

\subsection{Feeding and management:}

The rations offered to camels were calculated according to Banerjee (1988). Clean fresh water was offered freely to all camels.

\section{Methods:}

\subsection{Camel semen collection:}

Eight ejaculates were collected and evaluated from each camel during the breeding season according to Abd El-Raouf et al. (1975) at 0.8:00 and 10.00 a.m. using an artificial vagina (AV) as the method described by Zeidan (2002). The AV was filled with water at $50-55^{\circ} \mathrm{C}$ and the temperature inside the inner liner was stabilized at $45-50^{\circ} \mathrm{C}$. The ejaculates were usually comes in fractions. Fresh camel semen that has a jelly-like consistency is left for liquefaction for about 30-60 minutes to make the sperm attained motility.

\subsection{Semen extension :}

Semen samples were collected, pooled and evaluated for each camel and then diluted with lactose-yolk-citrate (LYC) extender (2.9g sodium citrate dehydrate, $0.04 \mathrm{~g}$ citric acid anhydrous, $1.25 \mathrm{~g}$ lactose and $10 \mathrm{ml}$ eggyolk per $100 \mathrm{ml}$ distilled water, $500 \mathrm{I} . \mathrm{U} / \mathrm{ml}$ penicillin and $500 \mu \mathrm{g}$ Streptomycin sulphate) according to Musa et al. (1992). Semen extension was carried out by adding the appropriate volume of the semen slowly to the extender as the method described by Salisbury et al. (1978). The dilution rate was $1 \mathrm{ml}$ semen : $3 \mathrm{ml}$ extender accoding to Musa et al. (1992).

Semen samples were immediately diluted with LYC extender and kep at $25-30^{\circ} \mathrm{C}$ for liquefaction in waterbath for $45 \mathrm{mins}$, where semen samples were shaked throughly at this time. Thereafter, the mixture was transported in glass containers to a cooled chamber cabinet at $5^{\circ} \mathrm{C}$ for 3 days.

\subsection{Chilling of semen at $5^{\circ} \mathrm{C}$ :}

The test tubes containing extended semen for each camel were placed in a $500 \mathrm{ml}$ beaker containing water at $30^{\circ} \mathrm{C}$ with a thermometer in order to facilitate periodic check of the temperature during cooling period. Another test tubes containing extended semen only were placed in the beaker to 
maintain the extended temperature similar to that of semen (all the test tubes were covered with dark plastic sheath). The beaker was placed in a refrigerator and gradually cooled till their temperature reached to $5^{\circ} \mathrm{C}$ during a period of 1.5-2.0 hours according to Musa et al. (1992). The cooled spermatozoa were kept at $5^{\circ} \mathrm{C}$ for up to 3 days. After each storage time (0,1,2 and 3 days), percentages of sperm motility, dead spermatozoa, abnormal spermatozoa, acrosome damage and chromatin damage of spermatozoa were recorded.

\section{Copulation time (minutes):}

Duration of copulation was measured from the time of penile intromission into the artificial vagina until withdrawal as the method described by Bravo et al. (2000).

\section{Semen characteristics:}

\subsection{Semen colour:}

Semen colour was determined by direct visual examination from the collecting tube (Bravo et al., 2000).

\subsection{Semen consistency:}

Semen consistency was qualified as viscous when semen did not drop from a Pasteur pipette, semi-viscous when some semen dropped from the Pasteur pipette to glass slide and liquid when semen was fluid and dropped readily from the Pasteur pipette according to Bravo et al. (2000).

\subsection{Semen-ejaculate volume (ml):}

Semen-ejaculate volume was determined using a conical graduated tube.

\subsection{Hydrogen-ion concentration $(\mathrm{pH})$ :}

Seminal $\mathrm{pH}$ value in the male dromedary camels was measured using universal indictor paper and standard commercial stains according to Karras (1952).

\subsection{Sperm motility $(\%)$ :}

Generally, camel sperm motility (\%) was detected as an oscillatory motion the flagellum but not progressive due to the viscous materials according to Campbell $\boldsymbol{e t}$ al. (1956). With regard to extended semen, percentage of sperm motility was determined using one drop of the extended semen after each storage period. The drop of the extended semen was covered by a warmed cover slip and immediately examined using high power magnification (400x).

\subsection{Storagability (\%):}

Storagability (\%) of the cooled camel spermatozoa refers to the percentage of original motile spermatozoa still motile after 3 days of storage time at $5^{\circ} \mathrm{C}$ as the method described by Yassen and El-Kamash (1970).

2.7. Dead spermatozoa $(\%)$ :

The eosin/nigrosin staining procedure was carried out by dissolving $1.67 \mathrm{gm}$ eosin and $10.00 \mathrm{gm}$ nigrosin in distilled water up to $100 \mathrm{ml}$ according to Hackett and Macpherson (1965). 


\subsection{Abnormal spermatozoa (\%) :}

The percentage of abnormal spermatozoa (\%) was determined in the same smears prepared for live/dead spermatozoa ratio (Watson, 1975).

2.9. Acrosome damage of spermatozoa $(\%)$ :

The percentages of acrosome damage (\%) of spermatozoa was estimated according to Watson (1975).

\subsection{Sperm-cell concentration $\left(\mathrm{x10}^{6} / \mathrm{ml}\right)$ :}

Sperm-cell concentration $\left(\times 10^{6} / \mathrm{ml}\right)$ was counted using haemocytometer according to Khan (1971).

2.11. Chromatin damage of spermatozoa $(\%)$ :

Toluidine blue staining was performed as the method described by Erenpreiss et al. (2004). Smears were fixed in ethanol-acetic acid glactial $(3: 1, \mathrm{v} / \mathrm{v})$ for $1 \mathrm{~min}$ and $70 \%$ ethanol for 3 mins. Smears were hydrolyzed for 20 mins in $1 \mathrm{Mm}$ HCL, rinsed by distilled water and air-dried. One droplet of $0.025 \%$ Toluidine blue in Mcllvaine buffer. Smears were evaluated with light microscope magnification (x1000). Percentage of chromatin damage was estimated by evaluating 300 spermatozoa in each smear. Spermatozoa stained as green to light blue were considered to have normal chromatin, while those stained dark blue to violet were considered to have damaged chromatin.

\subsection{Sperm DNA fragmentation Index (\%):}

Single and double-stranded sperm DNA fragmentation Index can be measured using the alkaline and neutral comet assays. The procedure was simultaneously performed in semen samples on two distinct slides. Different semen qualities were washed with HEPES/MOPS buffer. Then, $25-\mu 1$ aliquotes of spermatozoa was arranged on two pretreated slides of agarose gel and placed on a cold plate at $5^{\circ} \mathrm{C}$ for 4 minutes. Thereafter, the cover slips were carefully isolated, and the slides were washed with an excess of lysing buffer for 30 minutes, followed by a 10 minute wash in Tris-borate EDTA (TBE). In the neutral comet assay, electrophoresis was performed with a TBE arrangement of $20 \mathrm{~V}(1 \mathrm{~V} / \mathrm{cm})$ for 12 minutes and 30 seconds, with a subsequent wash with $0.9 \% \mathrm{NaCl}$ for 2 minutes. The slide was washed for 3 minutes at $5^{\circ} \mathrm{C}$ and electrophoresis was then performed in $0.03 \mathrm{M} \mathrm{NaOH}$ at $20 \mathrm{~V}(1 \mathrm{~V} / \mathrm{cm})$ for 4 minutes. Then, both slides were incubated in a neutralizing solution for 5 minutes with TBE for 2 minutes. The slides were dried in a graded series of ethyl alcohol solutions $(75 \%, 85 \%$, and $100 \%)$ for 2 minutes each. Finally, 300 Poor, Normal and Good quality of spermatozoa were assessed according to Enciso et al. (2011).

3. Sperm mensuration $(\mu \mathrm{m})$ :

Mensuration of spermatozoa was measured using calibrated eye-piece micrometer scale using Eosin-Nigrosin stain according to Campbell $\boldsymbol{e t} \boldsymbol{a l}$. (1956). Every pixel of the micrometer scale was represented of $0.085 \mu \mathrm{m}$ 
when an oil immersion lens (x100). The parameters of the mensuration of spermatozoa included length and width of sperm head as well as length and width of sperm tail according to Banaszewska et al. (2011).

\section{Blood serum constituents:}

Blood samples were collected pre-slaughter from jugular vein in the non-heparinized vacutainer tube for each camel in different ages and centrifuged for 15 minutes at $8000 \mathrm{RCF}$. Serum samples were taken weekly and stored at $-20^{\circ} \mathrm{C}$ until analysis. Total protein, Albumin, Globulin, Total cholesterol, Sodium, Potassium, Calcium, Total phosphorus, Zinc and Testosterone concentrations and activity of AST and ALT enzymes were recorded. Total protein, albumin and total cholesterol concentrations were determined colourimetrically according to the method described by Tietz (1982). Globulin level was calculated by subtraction of albumin content from the total protein content. Testosterone hormone concentration $\left(\mathrm{T}_{2}\right)$ was determined by Radioimmunoassay Technique (RIA) of Coa-Ab-Cont Kits (Diagnostic Products Corporation-Los Anglos, USA) according to Abraham (1977). Sodium, Potessum, Calcium, and Total Phosphorus concentrations were determined colourimetrically according to Tietz (1982). Zinc concentration was determined using 5P9 Atomic Absorption Spectrophotometry (Pye Unicam) as the method described by Willis (1960).

\section{Biochemical analysis in seminal plasma $\left(\mathrm{U} / \mathbf{1 0}^{6}\right.$ spermatozoa):}

After each storage times $(0,1,2$ and 3 days), the cooled semen was centrifuged for 15 minutes at $8000 \mathrm{RCF}$. Seminal plasma was separated and stored at- $20^{\circ} \mathrm{C}$ until assay of enzymes. Activity of aspartate aminotransaminase (AST) and alanine-aminotransaminase (ALT) enzymes (Spectroliv-UV Auto, LIU-2602, Labomed, USA) were recorded as the method described by Reitman and Frankle (1957).

\section{Fertility rate (\%):}

Semen was deposited into the uterus using an insemination gun to the internal cervical. Insemination has to be done using a porcine rubber insemination tube heated to $38^{\circ} \mathrm{C}$ to prevent cold shock.

She-camels were injected intramuscularly with 3000 IU of human chorionic gonadotropin (hCG) in the from of Proface (1ml-ampules packed by EPICO, Egypt, under licence from I.F. Serna, Rome, Italy) to induce ovulation (Anouassi et al., 1994). She-camels were artificially inseminated approximately $48 \mathrm{hrs}$ post hCG injection.

She-camels were divided into three groups as follows:

Group 1 (n-17) : She-camels were artificially inseminated with Poor quality semen $(2 \mathrm{ml})$ containing $100 \times 10^{6}$ motile spermatozoa.

Group 2 (n-18) : She-camels were artificially inseminated with Normal quality semen $(2 \mathrm{ml})$ containing $100 \times 10^{6}$ motile spermatozoa. 
Group 3 (n-18) : She-camels were artificially inseminated with Good quality semen $(2 \mathrm{ml})$ containing $100 \times 10^{6}$ motile spermatozoa.

Pregnancy rate was diagnosed at 60 days after the date of insemination.

\section{Statistical analysis :}

Data were statistically analyzed by one-way and two-way design (ANOVA) using General Linear model (GLM) procedure of SAS (SAS, 2006). Duncan's multiple range test (Duncan, 1955) was used to detect significant differences among means. Percentage values were transformed to arc-sin values before being statistically analyzed. Conception rates were analyzed by Chi-square test.

The following model used was as follows:

\section{The first experiment :}

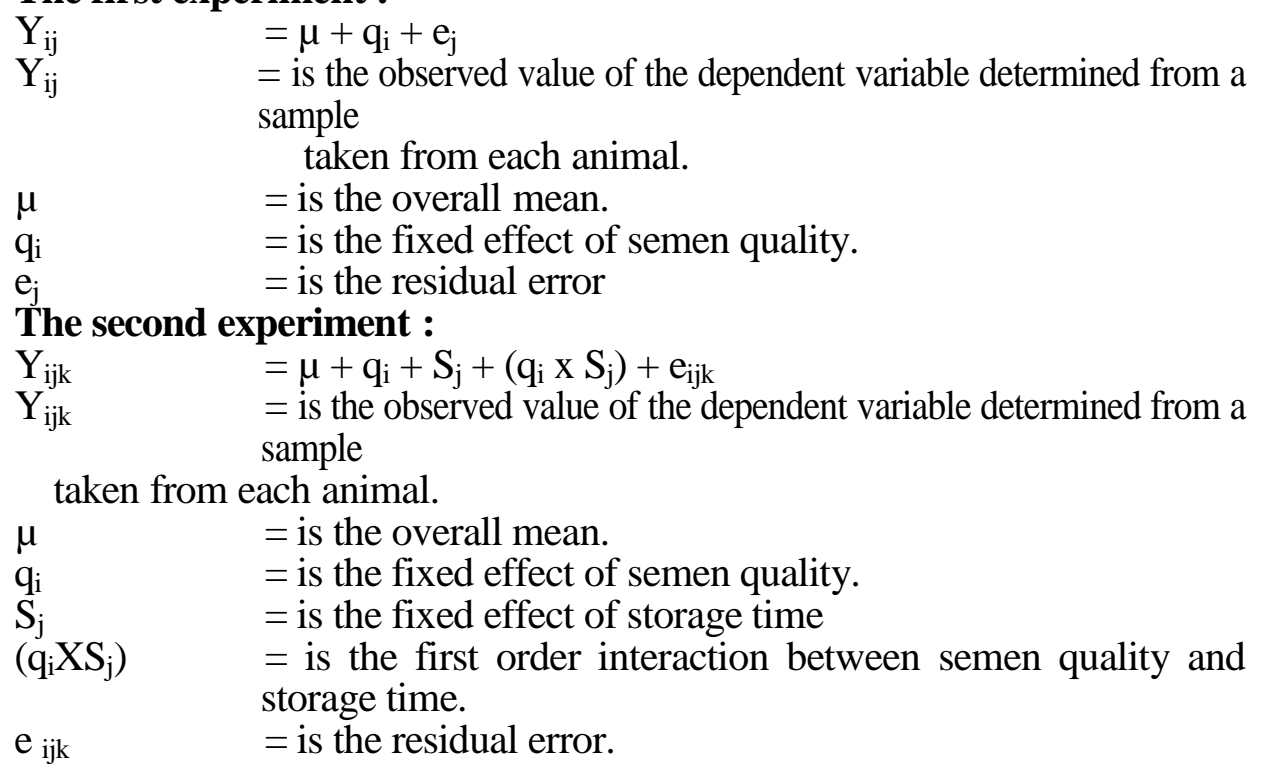

\section{The first experiment:}

\section{RESULTS AND DISCUSSION}

\section{Copulation time (minutes):}

Data presented in Table 1 showed that copulation time was significantly $(\mathrm{P}<0.05)$ better in the dromedary camel semen having Normal and Good quality than Poor quality of semen. It is generally increase of steroid hormone secretion, consequently increase of testosterone concentration which stimulate libido or copulation time, so this reflected on semen quality. These results are partially agreement with those of Zeidan $\boldsymbol{e t}$ al. (2001) in the male dromedary camels.

\section{Semen characteristics:}

\subsection{Semen colour :}

Semen colour was Thin creamy, Creamy and Creamy in the camels with Poor, Normal and Good semen quality, respectively (Table 1). The 
difference colour of semen quality may be due to the different concentrations of spermatozoa and semen consistency. Similar trends were recorded by Zeidan et al. (2001) in the male dromedary camel.

\subsection{Semen consistency:}

Semen consistency was Semi-viscous, Viscous and Viscous for camels with Poor, Normal and Good quality, respectively (Table 1). Viscosity of semen is usually attributed to the presence of mucopolysacharides (Garnica et al., 1993) which can be secreted from bulbourethral glands or the prostate gland.

\subsection{Semen-ejaculate volume ( $\mathrm{ml})$ :}

Semen-ejaculate volume showed significantly $(\mathrm{P}<0.05)$ higher of the dromedary camels having Normal and Good quality than Poor quality of semen (Table 1). Similar trends were recorded by Zeidan et al. (2001) and Matter (2019) in the dromedary camel.

\subsection{Hydrogen-ion concentration $(\mathrm{pH})$ :}

Data presented in Table 1 showed that seminal hydrogen-ion concentration $(\mathrm{pH})$ value was insignificantly different in the dromedary camel with different qualities of semen (Poor, Normal and Good).

\subsection{Percentage of sperm motility:}

The percentage of sperm motility was significantly $(\mathrm{P}<0.05)$ higher of the male dromedary camel having Good quality than Poor and Normal quality of semen (Table 1). Similarly, the percentage of sperm motility was significantly $(\mathrm{P}<0.05)$ higher in the dromedary camel semen having Good quality than Poor and Normal quality of semen. These results may be due to the hypoactive of Leydig cells which are considered to be testosterone hormone producing factor, so this reflected on semen quality. Similar trends were recorded by Zeidan et al. (2001) and Matter (2019) in the male dromedary camels.

\subsection{Percentage of dead spermatozoa :}

Data presented in Table 1 showed that the percentage of dead camel spermatozoa was significantly $(\mathrm{P}<0.05)$ higher of the male dromedary camel semen in the camels with Poor quality than Normal and Good quality of semen. The highest $(\mathrm{P}<0.05)$ value of the percentage of dead spermatozoa of the Poor quality of semen may be attributed to the disturbance in spermatogenesis process or even death of spermatozoa which reflected on a bad semen quality. Similar trends were recorded by Zeidan et al. (2001) and Matter (2019) in the male dromedary camels.

\subsection{Percentage of abnormal spermatozoa:}

The percentage of abnormal spermatozoa was significantly $(\mathrm{P}<0.05)$ higher of the male dromedary camel semen having Poor quality than Normal and Good quality of semen (Table 1$)$. The highest $(\mathrm{P}<0.05)$ value of percentage of abnormal camel spermatozoa was recorded with Poor quality and the lowest $(\mathrm{P}<0.05)$ value was recorded with Good quality of semen. 


\subsection{Percentage of acrosome damage:}

The percentage of acrosome damage was significantly $(\mathrm{P}<0.05)$ higher of the dromedary camel having Good quality than Normal and Poor quality of semen (Table 1$)$. The highest $(\mathrm{P}<0.05)$ value of the percentage of acrosome damage of spermatozoa was recorded with Poor quality of semen and the lowest $(\mathrm{P}<0.05)$ value was recorded with Good quality in the dromedary camel semen.

\subsection{Percentage of chromatin damage:}

Data presented in Table 1 revealed that the percentage of chromatin damage of spermatozoa in the dromedary camels was significantly $(\mathrm{P}<0.05)$ decreased with the Normal and Good quality of camels compared to those with Poor quality of semen. These results may be attributed to the decrease of adenosine triphosphate which activated apparently ability of resynthesizing. This was accompanied with precipitation full in the rate of fructolysis, consequently increased chromatin damage (Mann and Lutwak-Mann, 1981).

\subsection{Sperm-cell concentration $\left(\mathrm{x}^{6} \% \mathrm{ml}\right)$ :}

Sperm-cell concentration was significantly $(\mathrm{P}<0.05)$ higher of the dromedary camel having Normal and Good quality than Poor quality of semen (Table 1). The highest $(\mathrm{P}<0.05)$ value of sperm-cell concentration $\left(\mathrm{x} 10^{6} / \mathrm{ml}\right)$ was recorded with Normal and Good quality of semen, while the lowest $(\mathrm{P}<0.05)$ value was recorded with Poor quality of semen in the dromedary camels. Similar trends were recorded by Zeidan et al. (2001) and Matter (2019) in the male dromedary camels. These results may be due to the hyperactive of Leydig cells which are increase of testosterone hormone secretion which more in the camels having Normal and Good quality than Poor quality of semen.

\subsection{Sperm DNA fragmentation Index $(\%)$ :}

The percentage of sperm DNA fragmentation Index of the dromedary camels was significantly $(\mathrm{P}<0.05)$ decreased in the camels having Normal and Good quality of semen compared to those with Poor quality of semen (Table 1). In fact sperm abnormalities could finally produce DNA degradation as part of an apoptotic process to eliminate defective sperm cells. Consequently, most of the morphologically abnormal and DNA fragmented spermatozoa present in the ejaculate.

On the other hand, the morphological abnormalities might potentially have a genetic origin. Sperm DNA damage could be considered as the physiological basis of some morphological defects. Some investigators confirmed that certain aspects of fertility including morphological abnormalities are probably under genetic control (Chenoweth, 2005).

Moreover, as morphologically normal spermatozoa can also present with DNA damage, the inclusion of the assessment of DNA fragmentation in traditional semen analysis is likely to provide a more through evaluation 
of semen quality and lead to a better ability to predict male fertility. A combination of sperm chromatin Dispersion (SCD) test is likely to improve semen quality assessment and lead to more informed decisions, when predicting male reproductive efficiency (Enciso et al., 2011) in bull spermatozoa. In a similar experimental fashion, the SCD test was used to show the incidence of aneuploidies in spermatozoa containing fragmemented DNA (Enciso et al., 2011). In addition, sperm DNA fragmentation has been reported to have a negative effect on fertility and embryo development (Garcia-Macias et al., 2007) in bull spermatozoa. The relationship between morphological abnormalities and DNA fragmentation suggests that the use of SCD for the simultaneous evaluation of sperm morphology and DNA damage may be useful for the detection of these defective cells (Enciso et al., 2011).

Table 1 : Copulation time, semen characteristics and DNA Fragmentation Index of the different semen qualities in the male dromedary camels (Means \pm SE).

\begin{tabular}{|c|c|c|c|}
\hline \multirow[t]{2}{*}{ Items } & \multicolumn{3}{|c|}{ Semen quality } \\
\hline & Poor & Normal & Good \\
\hline Copulation time (min) & $2.65 \pm 0.08^{b}$ & $5.16 \pm 0.07^{\mathrm{a}}$ & $5.74 \pm 0.04^{\mathrm{a}}$ \\
\hline Semen colour & Thin Creamy & Creamy & Creamy \\
\hline Semen Consistency & Semi-viscous & Viscous & Viscous \\
\hline Semen-eja. volume $(\mathrm{ml})$ & $4.08 \pm 0.03^{b}$ & $6.24 \pm 0.07^{\mathrm{a}}$ & $6.75 \pm 0.08^{a}$ \\
\hline Hydro. ion concen. $(\mathrm{pH})$ & $8.02 \pm 0.06^{\mathrm{a}}$ & $7.65 \pm 0.13^{\mathrm{a}}$ & $7.59 \pm 0.12^{\mathrm{a}}$ \\
\hline Sperm motility (\%) & $28.75 \pm 0.29^{c}$ & $57.92 \pm 0.36^{b}$ & $75.11 \pm 0.89^{\mathrm{a}}$ \\
\hline Dead spermatozoa $(\%)$ & $70.68 \pm 0.89^{\mathrm{a}}$ & $23.86 \pm 0.39^{b}$ & $21.94 \pm 0.22^{b}$ \\
\hline Abnormal spermatozoa (\%) & $43.51 \pm 0.61^{\mathrm{a}}$ & $15.14 \pm 0.12^{b}$ & $13.52 \pm 0.13^{b}$ \\
\hline Acrosome damage (\%) & $16.93 \pm 0.18^{\mathrm{a}}$ & $7.19 \pm 0.18^{b}$ & $5.96 \pm 0.11^{b}$ \\
\hline Chromatin damage $(\%)$ & $6.48 \pm 0.11^{\mathrm{a}}$ & $2.87 \pm 0.02^{b}$ & $2.14 \pm 0.06^{b}$ \\
\hline Sperm-cell concentration $\left(\times 10^{6} / \mathrm{ml}\right)$ & $216.23 \pm 8.15^{c}$ & $374.81 \pm 11.69^{b}$ & $392.56 \pm 2.17^{\mathrm{a}}$ \\
\hline DNA Fragmentation Index (\%) & $19.62 \pm 0.46^{\mathrm{a}}$ & $5.17 \pm 0.29^{b}$ & $3.98 \pm 0.24^{b}$ \\
\hline
\end{tabular}

a-c Within a row, within semen quality, means with different superscripts letters differ significantly $(\mathrm{P}<0.05)$.

\section{Sperm mensuration $(\mu \mathrm{m})$ :}

Sperm mensuration measurements $(\mu \mathrm{m})$ of the dromedary camels was insignificantly affects with different semen qualities of the dromedary camels (Table 2). Total length of the camel spermatozoa was insignificantly higher in the camels having Good quality of semen than both Poor and Normal quality of semen. Similar trends were reported by Zeidan (1999) in the dromedary camels.

Fertilizing ability of spermatozoa depends on the status of their shapes and sizes, which affect the course of the acrosomal reaction and sperm penetration of the ovum (Kondracki et al., 2011). Generally, male age is one of the significantly causes of variation of spermatozoa morphology and morphometric dimensions (Banaszewska et al., 2011). 
Table 2 : Effects of semen quality on sperm mensuration $(\mu \mathrm{m})$ measurements of the male dromedary camels (Means \pm SE).

\begin{tabular}{|l|c|c|c|c|}
\hline \multirow{2}{*}{ Sperm mensuration $(\mu \mathrm{m})$} & \multicolumn{3}{|c|}{ Semen quality } & \multirow{2}{*}{ Significance } \\
\cline { 2 - 4 } & Poor & Normal & Good & \\
\hline Head of spermatozoa: & & & & NS \\
\hline Head length & $\mathbf{6 . 0 2} \pm 0.08$ & $6.13 \pm 0.12$ & $6.17 \pm 0.14$ & NS \\
\hline Head width & $2.60 \pm 0.04$ & $2.81 \pm 0.06$ & $2.83 \pm 0.05$ & NS \\
\hline Head breadth & $3.16 \pm 0.06$ & $3.25 \pm 0.07$ & $3.29 \pm 0.11$ & NS \\
\hline Head shape index & 0.43 & 0.45 & 0.45 & \\
\hline $\begin{array}{l}\text { Tail of spermatozoa } \\
\text { Mid, Main and End piece): }\end{array}$ & & & & NS \\
\hline Tail length & $45.73 \pm 0.61$ & $45.80 \pm 0.68$ & $45.92 \pm 0.72$ & NS \\
\hline Tail width & $1.38 \pm 0.02$ & $1.54 \pm 0.05$ & $1.57 \pm 0.06$ & NS \\
\hline Tail breadth & $1.69 \pm 0.06$ & $1.76 \pm 0.08$ & $1.83 \pm 0.05$ & NS \\
\hline Tail shape index & 7.59 & 7.47 & 7.44 & NS \\
\hline Total length & $51.75 \pm 0.74$ & $51.93 \pm 0.82$ & $52.09 \pm 0.91$ & \\
\hline
\end{tabular}

Head shape index $=$ Width/length ratio.

Tail shape index = Tail length / Head length ratio.

\section{Blood serum constituents:}

\subsection{Total protein, albumin and globulin concentrations $(\mathrm{gm} / \mathrm{dI})$ :}

Data presented in Table 3 showed that total protein, albumin and globulin concentrations $(\mathrm{gm} / \mathrm{dI})$ in the blood serum were not significant with different semen qualities of the male dromedary camels. Total protein, albumin and globulin concentrations of the blood serum were insignificantly higher in the camels having Normal and Good quality than Poor semen quality. The decrease of total protein with Poor semen quality may be attributed to low semen characteristics and adaptability of camels which represented the potent stimulus of semen quality. Similar trends were reported by Amin et al. (2007) of the dromedary camels.

4.2. Total cholesterol and testosterone concentrations $(\mathrm{mg} / 100 \mathrm{ml})$ :

Total cholesterol and testosterone concentrations $(\mathrm{mg} / \mathrm{dI})$ in the blood serum of the male dromedary camels were significantly $(\mathrm{P}<0.05)$ increased with Normal and Good quality of semen compared to those with Poor quality of semen (Table 3$)$. The highest $(\mathrm{P}<0.05)$ values of the total cholesterol and testosterone concentrations in the blood serum of the male dromedary camels were recorded with Good semen quality than either Normal or Poor semen quality, while the lowest $(\mathrm{P}<0.05)$ values were recorded in the camels having Poor semen quality. Khan and Kohli (1973) showed higher values in cholesterol concentration of the male camels before and during rut. It was ranged from 49.8 to $85.3 \mathrm{mg} / 100 \mathrm{ml}$ of with a mean value of $65.58 \mathrm{mg} / 100 \mathrm{ml}$. Moreover, blood serum testosterone of the male dromedary camels was significantly higher which is parallel to increase of sexual activity. This reflect the fact that the high androgen in the male camel with the direct cause of the characteristics of its sexual behavior in the camels having Normal and Good quality of semen. These results are partially agreement with those of Bedrak et al. (1983) and Zeidan et al.(2001) in the male dromedary camel. 


\subsection{Mineral concentrations $(\mathrm{mg} / 100 \mathrm{ml})$ :}

Sodium concentration $(\mathrm{mg} / 100 \mathrm{ml})$ in the blood serum of the male dromedary camels was significantly $(\mathrm{P}<0.05)$ increased in the camel having Poor quality of semen compared to those with Normal and Good quality of semen (Table 3$)$. The highest $(\mathrm{P}<0.05)$ value of blood sodium concentration of the male dromedary camels was recorded with Poor semen quality. While, the lowest $(\mathrm{P}<0.05)$ value was recorded with Good semen quality. These results may be attributed to the combined effects of both absorption and reabsorption of sodium and chloride from the alimentary tract and Kidney, under the effect of aldosterone hormone which had higher levels with Poor quality of semen and this was accompanied by increase of plasma sodium level (Yagil and Etzion, 1979).

However, Potassium, Calcium and Total phosphorous concentrations $(\mathrm{gm} / 100 \mathrm{ml})$ and Zinc concentrations $(\mu \mathrm{g} / 100 \mathrm{ml})$ in the blood serum of the male camels were significantly $(\mathrm{P}<0.05)$ higher of the camels having Normal and Good quality of semen than Poor quality of semen (Table 3). The decrease in potassium concentration in the camels having Poor semen quality may be due to lower semen characteristics than Normal or Good semen quality of the male dromedary camels. Similarly, the increase of Calcium, Total phosphorus and Zinc concentrations may be high feed efficiency and metabolic rate of the camels having Normal and Good semen quality, consequently high semen quality compared to those with camels having Poor semen quality (Table 3). Similar findings were reported by Zeidan and Abbas (2004) and Amin et al. (2007) of the male dromedary camel.

\subsection{Enzymatic activity (U/L):}

Activity of AST and ALT enzymes in blood serum of the male dromedary camels was significantly $(\mathrm{P}<0.05)$ higher of the camel having Poor quality of semen than Normal and Good quality of semen (Table 3). Similarly, the activity of the blood serum AST and ALT enzymes was significantly $(\mathrm{P}<0.05)$ increased in the camels having Normal semen quality compared to those with Good semen quality (Table 3). In general, the blood enzymes are easily and often influenced by the external condition including feeding practices, type of shelter and many other aspects of the herd management, since they are ultimately related to metabolism especially environmental ones when measuring the enzyme activity in any animal the adaptability of the camels having Normal and Good semen quality was significantly better than camels with Poor semen quality. Similar trends were recorded by Zeidan and Abbas (2004) and Matter (2019). 
Table 3: Effects of different semen quality on blood serum constituents of the male dromedary camels (Means \pm SE).

\begin{tabular}{|c|c|c|c|c|}
\hline \multirow{2}{*}{\multicolumn{2}{|c|}{ Items }} & \multicolumn{3}{|c|}{ Semen quality } \\
\hline & & Poor & Normal & Good \\
\hline Total protein & $(\mathrm{gm} / \mathbf{1 0 0 m l})$ & $6.84 \pm 0.21^{\mathrm{a}}$ & $7.03 \pm 0.23^{a}$ & $7.52 \pm 0.32^{\mathrm{a}}$ \\
\hline Albumin & $(\mathrm{gm} / \mathbf{1 0 0 m l})$ & $3.50 \pm 0.16^{\mathrm{a}}$ & $3.62 \pm 0.15^{\mathrm{a}}$ & $3.74 \pm 0.19^{a}$ \\
\hline Globulin & $(\mathrm{gm} / \mathbf{1 0 0 m l})$ & $3.34 \pm 0.15^{\mathrm{a}}$ & $3.41 \pm 0.19^{a}$ & $3.78 \pm 0.21^{\mathrm{a}}$ \\
\hline Total cholesterol & $(\mathrm{mg} / 100 \mathrm{ml})$ & $30.72 \pm 18.23^{b}$ & $82.35 \pm 20.16^{a}$ & $84.13 \pm 34.11^{a}$ \\
\hline Sodium & (mg/100ml) & $175.19 \pm 6.18^{a}$ & $142.15 \pm 5.11^{b}$ & $123.17 \pm 3.48^{c}$ \\
\hline Potassium & (mg/100ml) & $1.62 \pm 0.13^{c}$ & $11.85 \pm 0.38^{b}$ & $13.68 \pm 0.42^{\mathrm{a}}$ \\
\hline Calcium & $(\mathrm{mg} / 100 \mathrm{ml})$ & $4.12 \pm 0.19^{c}$ & $9.43 \pm 0.35^{b}$ & $12.16 \pm 0.40^{\mathrm{a}}$ \\
\hline Total phosphorus & $(\mathrm{mg} / 100 \mathrm{ml})$ & $2.16 \pm 0.14^{c}$ & $5.38 \pm 0.26^{b}$ & $9.14 \pm 0.28^{\mathrm{a}}$ \\
\hline Zinc & $(\mu \mathrm{g} / 100 \mathrm{ml})$ & $87.11 \pm 2.14^{c}$ & $113.45 \pm 4.23^{b}$ & $128.50 \pm 5.18^{\mathrm{a}}$ \\
\hline Aspartate-aminotransaminase & $(\mathbf{U} / \mathrm{L})$ & $46.12 \pm 0.73^{\mathrm{a}}$ & $34.60 \pm 0.51^{b}$ & $28.35 \pm 0.38^{c}$ \\
\hline Alanine- aminotransaminase & $(\mathbf{U} / \mathbf{L})$ & $62.13 \pm 0.81^{\mathrm{a}}$ & $50.22 \pm 0.64^{b}$ & $41.53 \pm 0.47^{\mathrm{c}}$ \\
\hline Testosterone concentration & $(\mathrm{ng} / \mathrm{ml})$ & $0.98 \pm 0.12^{c}$ & $3.91 \pm 0.15^{b}$ & $6.02 \pm 0.19^{a}$ \\
\hline
\end{tabular}

a-c : Within a rows, within semen quality, means with different superscripts letters differ significantly $(\mathrm{P}<0.05)$.

\section{The second experiment:}

\section{Percentage of motile camel spermatozoa:}

The percentages of motile and storagability of the diluted camel spermatozoa with LYC extender were significantly $(\mathrm{P}<0.05)$ increased of the camels having Normal and Good semen quality compared to these with Poor semen quality during storage at $5^{\circ} \mathrm{C}$. Similarly, Good quality of the diluted camel spermatozoa with LYC extender showed significantly $(\mathrm{P}<0.05)$ higher of the percentages of sperm motility and sperm storagability than Normal quality of spermatozoa stored at $5^{\circ} \mathrm{C}$ (Table 4). These changes in sperm motility and sperm sperm storagability are consistent with the idea that there is a transition of semen quality from high with Good quality of semen to low with poor quality of semen. Similar trends were reported by Zhang et al. (2001) in bull spermatozoa.

It is of interest to note that the prolongation of storage time at $5^{\circ} \mathrm{C}$ decreased significantly $(\mathrm{P}<0.05)$ percentage of motile camel spermatozoa (Table 4). In all semen qualities, percentage of motility of the cooled camel spermatozoa was significantly $(\mathrm{P}<0.05)$ maintained during the first day and then decreased significantly $(\mathrm{P}<0.05)$ as time of storage increase. These results are in agreement with those of Zhang et al. (2001) in bull spermatozoa. These findings may be due to that the increase of sperm motility in the first day of storage causes an increase in sperm metabolic activity, consequently increase of lactic acid production which in turn exerts a toxic effect of the sperm cells. This phenomenon may be attributed to decrease in the content of adenosine triphosphate which activated spermatozoa apparently ability of resynthesizing. This was accompanied with a precipitous fall in the rate of fructolysis (Mann and Lutwak-Mann, 1981). 
Table 4 : Mean percentages of motile and storagability of the dromedary camel spermatozoa during storage at $5^{\circ} \mathrm{C}$ for up to 3 days (Means \pm SE).

\begin{tabular}{|c|c|c|c|c|}
\hline \multirow{2}{*}{$\begin{array}{c}\begin{array}{c}\text { Storage time } \\
\text { (days) }\end{array} \\
\end{array}$} & \multicolumn{3}{|c|}{ Semen quality } & \multirow[t]{2}{*}{ Mean } \\
\hline & Poor & Normal & Good & \\
\hline 0 & $36.19 \pm 0.28$ & $54.82 \pm 0.60$ & $68.23 \pm 0.74$ & $53.08 \pm 0.60^{a}$ \\
\hline 1 & $30.25 \pm 0.24$ & $49.16 \pm 0.52$ & $65.11 \pm 0.70$ & $48.17 \pm 0.53^{b}$ \\
\hline 2 & $21.38 \pm 0.18$ & $43.67 \pm 0.51$ & $60.24 \pm 0.65$ & $41.76 \pm 0.50^{\mathrm{c}}$ \\
\hline 3 & $8.92 \pm 0.11$ & $28.14 \pm 0.32$ & $45.69 \pm 0.52$ & $27.58 \pm 0.37^{d}$ \\
\hline Overall mean & $24.18 \pm 0.19^{C}$ & $43.94 \pm 0.50^{B}$ & $59.81 \pm 0.62^{\mathrm{A}}$ & 42.64 \\
\hline Storagability (\%) & 24.64 & 54.33 & 66.96 & 51.95 \\
\hline
\end{tabular}

A-C Values with different superscripts within a row are significantly different $(\mathrm{P}<0.05)$. a-d Values with different superscripts within a column are significantly different $(\mathrm{P}<0.05)$.

\section{Percentage of dead camel spermatozoa:}

The percentage of dead camel diluted spermatozoa with LYC extender was significantly $(\mathrm{P}<0.05)$ decreased in the camels having Normal and Good quality of semen compared to those with Poor quality of semen during storage at $5^{\circ} \mathrm{C}$ for 3 days (Table 5). These findings may be due to bad semen quality, consequently Poor quality of semen.

The prolongation of storage time at $5^{\circ} \mathrm{C}$ increased significantly $(\mathrm{P}<0.05)$ the percentage of dead camel spermatozoa with all different semen qualities (Table 5). The percentage of dead spermatozoa increased significantly $(\mathrm{P}<0.05)$ as time of storage increase. Shannon and Curson (1972) found that dead spermatozoa were a source of amino acid oxidase which cause the production of $\mathrm{H}_{2} \mathrm{O}_{2}$, consequently, increased the percentage of dead spermatozoa as the time of storage increase. Similar trend was reported by Zeidan (2002) in the dromedary camel spermatozoa.

Table 5 : Mean percentages of dead camel spermatozoa during storage at $5^{\circ} \mathrm{C}$ for up to 3 days (Means \pm SE).

\begin{tabular}{|c|c|c|c|c|}
\hline \multirow{2}{*}{$\begin{array}{c}\text { Storage time } \\
\text { (days) }\end{array}$} & \multicolumn{3}{|c|}{ Semen quality } & \multirow[t]{2}{*}{ Mean } \\
\hline & Poor & Normal & Good & \\
\hline $\mathbf{0}$ & $61.13 \pm 0.72$ & $42.18 \pm 0.38$ & $21.87 \pm 0.13$ & $41.72 \pm 0.39^{\mathrm{d}}$ \\
\hline 1 & $64.71 \pm 0.75$ & $45.76 \pm 0.52$ & $24.93 \pm 0.17$ & $45.13 \pm 0.53^{c}$ \\
\hline 2 & $76.18 \pm 0.81$ & $50.65 \pm 0.63$ & $35.74 \pm 0.28$ & $54.19 \pm 0.64^{\mathrm{b}}$ \\
\hline 3 & $87.22 \pm 0.93$ & $65.18 \pm 0.76$ & $50.16 \pm 0.61$ & $67.52 \pm 0.84^{\mathrm{a}}$ \\
\hline Overall mean & $72.31 \pm 0.82^{A}$ & $50.94 \pm 0.65^{\mathrm{B}}$ & $33.17 \pm 0.26^{\mathrm{C}}$ & 52.14 \\
\hline
\end{tabular}

$\mathrm{A}-\mathrm{C}$ Values with different superscripts within a row are significantly different $(\mathrm{P}<0.05)$. a-d Values with different superscripts within a column are significantly different $(\mathrm{P}<0.05)$.

\section{Percentage of abnormal camel spermatozoa:}

The percentage of abnormal camel spermatozoa diluted with LYC extender was significantly $(\mathrm{P}<0.05)$ decreased in the camels having Normal and Good quality of semen compared to those with Poor quality of semen during storage at $5^{\circ} \mathrm{C}$. In addition, the percentage of diluted 
camel spermatozoa with LYC extender showed significantly $(\mathrm{P}<0.05)$ higher in the camel having Good quality than Normal quality of semen stored at $5^{\circ} \mathrm{C}$ (Table 6).

It was a very potent and efficient endogenous radical scavenger. It reacted with the highly toxic hydroxyl radical and provides protection against oxidative damage to biomolecules. These results are in agreement with those obtained by Zhang et al. (2001) in bull spermatozoa.

It is of interest to note that the prolongation of storage time at $5^{\circ} \mathrm{C}$ increased significantly $(\mathrm{P}<0.05)$ the percentage of abnormal camel spermatozoa with all different semen qualities (Table 6). These results are in agreement with those of Zhang et al. (2001) in bull spermatozoa.

Table 6 : Mean percentages of abnormal camel spermatozoa during storage at $5^{\circ} \mathrm{C}$ for up to 3 days (Means \pm SE).

\begin{tabular}{|c|c|c|c|c|}
\hline \multirow{2}{*}{$\begin{array}{c}\text { Storage time } \\
\text { (days) }\end{array}$} & \multicolumn{3}{|c|}{ Semen quality } & \multirow[t]{2}{*}{ Mean } \\
\hline & Poor & Normal & Good & \\
\hline $\mathbf{0}$ & $34.15 \pm 0.43$ & $19.23 \pm 0.23$ & $8.62 \pm 0.09$ & $20.66 \pm 0.25^{d}$ \\
\hline 1 & $41.26 \pm 0.57$ & $20.69 \pm 0.26$ & $9.51 \pm 0.11$ & $23.82 \pm 0.30^{c}$ \\
\hline 2 & $53.18 \pm 0.61$ & $26.14 \pm 0.31$ & $12.36 \pm 0.16$ & $30.56 \pm 0.40^{b}$ \\
\hline 3 & $64.59 \pm 0.84$ & $35.92 \pm 0.46$ & $17.83 \pm 0.18$ & $39.44 \pm 0.52^{\mathrm{a}}$ \\
\hline Overall mean & $48.29 \pm 0.63^{A}$ & $25.49 \pm 0.34^{B}$ & $12.08 \pm 0.17^{\mathrm{C}}$ & 28.62 \\
\hline
\end{tabular}

$\mathrm{A}-\mathrm{C}$ Values with different superscripts with a row are significantly different $(\mathrm{P}<0.05)$.

a-d Values with different superscripts with a column are significantly different $(\mathrm{P}<0.05)$.

\section{Percentage of acrosome damage of spermatozoa:}

The percentage of acrosome damage of camel spermatozoa as affected by semen quality of semen during storage at $5^{\circ} \mathrm{C}$ was significant $(\mathrm{P}<0.05)$. The highest $(\mathrm{P}<0.05)$ value of the percentage of acrosome damage of spermatozoa was recorded in the camel having Poor quality of semen, while the lowest $(\mathrm{P}<0.05)$ value was recorded in the camels having Normal and Good quality of semen during storage at $5^{\circ} \mathrm{C}$ (Table 7).

Jones and Stewart (1979) indicated that extension and cooling of bull semen to $5^{\circ} \mathrm{C}$ caused acrosome swelling in about $50 \%$ of the spermatozoa. Subsequent freezing and thawing caused considerable ultrastructural changes to the acrosomes (disruption of the plasma and outer acrosome membranes and dispersion of the acrosomal (disruption of the plasma and outer acrosome membranes and dispersion of the acrosomal contents) and middle pieces (breakage of the plasma membrane and a reduction in the electron density of the mitochondrial matrix) of a high proportion of spermatozoa.

Moreover, storage of semen at low temperatures caused structural damage as a result of cold shock. The changes involved damage to the plasma membrane over the acrosome and the outer acrosome membrane and damage to the plasma membrane of the middle piece. These changes are followed by a decrease in the proportion of spermatozoa with intact 
acrosomes and an increase in the release of enzymes into the extracellular medium. Therefore, the morphological characteristics of sperm acrosomes and enzymes concentration in the extracellular medium with initial motility gives the best indication so far of initial quality, especially for frozen bull semen (Zeidan et al., 1998).

The prolongation of storage time at $5^{\circ} \mathrm{C}$ increased significantly $(\mathrm{P}<0.05)$ the percentage of acrosome damage of the cooled camel spermatozoa with all different semen qualities during storage at $5^{\circ} \mathrm{C}$ (Table 7). These results are in agreement with those of Zhang $\boldsymbol{e t}$ al. (2001) in bull spermatozoa.

Table 7 : Mean percentages of acrosome damage of the camel spermatozoa during storage at $5^{\circ} \mathrm{C}$ for up to 3 days (Means \pm SE).

\begin{tabular}{|c|c|c|c|c|}
\hline \multirow{2}{*}{$\begin{array}{c}\text { Storage time } \\
\text { (days) }\end{array}$} & \multicolumn{3}{|c|}{ Semen quality } & \multirow[t]{2}{*}{ Mean } \\
\hline & Poor & Normal & Good & \\
\hline $\mathbf{0}$ & $16.50 \pm 0.09$ & $8.23 \pm 0.05$ & $3.17 \pm 0.02$ & $9.30 \pm 0.06^{d}$ \\
\hline 1 & $19.73 \pm 0.11$ & $10.64 \pm 0.07$ & $4.26 \pm 0.03$ & $11.54 \pm 0.09^{c}$ \\
\hline 2 & $28.91 \pm 0.17$ & $17.32 \pm 0.10$ & $6.15 \pm 0.05$ & $17.46 \pm 0.12^{b}$ \\
\hline 3 & $40.26 \pm 0.23$ & $23.54 \pm 0.14$ & $10.32 \pm 0.08$ & $24.70 \pm 0.16^{a}$ \\
\hline Overall mean & $26.35 \pm 0.19^{A}$ & $14.93 \pm 0.08^{B}$ & $5.97 \pm 0.03^{C}$ & 15.75 \\
\hline
\end{tabular}

A-C Values with different superscripts within a row are significantly different $(\mathrm{P}<0.05)$. a-d Values with different superscripts within a column are significantly different $(\mathrm{P}<0.05)$.

5. Percentage of chromatin damage $(\%)$ :

The percentage of chromatin damage of the diluted camel spermatozoa with LYC extender was significantly $(\mathrm{P}<0.05)$ lower of the camels having Normal and Good quality of semen than Poor quality of semen during storage at $5^{\circ} \mathrm{C}$ for up to 3 days. Moreover, the percentage of diluted camel spermatozoa with LYC extender was significantly $(\mathrm{P}<0.05)$ increased of the camels having Good quality of semen compared to those camels with Normal semen quality (Table 8). Similar trends were recorded by Zeidan et al. (2001) and Matter (2019) in the dromedary camel spermatozoa.

There are many fluctuations in damage of DNA spermatozoa such as imperfect of spermatogenesis process, apoptosis, reactive oxygen species, in vitro handling, type of extender and cryopreservation stress (Baiee et al., 2017). Lioyd et al. (2012) confirmed that sperm DNA integrity was better in commercial diluent could be significantly increased DNA fragmentation during at $5^{\circ} \mathrm{C}$ for 48 hours. Similar tends were recorded by Matter (2019) in the dromedary camel spermatozoa.

It is of interest to note that the prolongation of storage time at $5^{\circ} \mathrm{C}$ for 3 days was significantly $(\mathrm{P}<0.05)$ increased the percentage of chromatin damage of the camel spermatozoa in all different semen qualities (Table 8). These results are in agreement with those of Matter (2019) in the male dromedary camel spermatozoa. 
Table 8 : Mean percentages of chromatin damage of the camel spermatozoa during storage at $5^{\circ} \mathrm{C}$ for 3 days (Means $\pm \mathrm{SE}$ ).

\begin{tabular}{|c|c|c|c|c|}
\hline \multirow{2}{*}{$\begin{array}{c}\begin{array}{c}\text { Storage time } \\
\text { (days) }\end{array} \\
\end{array}$} & \multicolumn{3}{|c|}{ Semen quality } & \multirow[t]{2}{*}{ Mean } \\
\hline & Poor & Normal & Good & \\
\hline 0 & $8.12 \pm 0.04$ & $4.18 \pm 0.02$ & $2.10 \pm 0.01$ & $4.80 \pm 0.03^{d}$ \\
\hline 1 & $10.13 \pm 0.05$ & $5.76 \pm 0.04$ & $2.89 \pm 0.01$ & $6.26 \pm 0.04^{\mathrm{c}}$ \\
\hline 2 & $15.06 \pm 0.10$ & $7.14 \pm 0.05$ & $5.18 \pm 0.03$ & $9.12 \pm 0.06^{b}$ \\
\hline 3 & $20.72 \pm 0.12$ & $11.64 \pm 0.06$ & $8.39 \pm 0.06$ & $13.58 \pm 0.10^{a}$ \\
\hline Overall mean & $13.50 \pm 0.11^{\mathrm{A}}$ & $7.18 \pm 0.06^{B}$ & $4.64 \pm 0.02^{C}$ & 8.44 \\
\hline
\end{tabular}

$\mathrm{A}-\mathrm{C}$ Values with different superscripts within a row are significantly different $(\mathrm{P}<0.05)$. a-d Values with different superscripts within a column are significantly different $(\mathrm{P}<0.05)$.

6. Enzymatic activity (U/10 ${ }^{6}$ spermatozoa):

Activity of AST and ALT enzymes in the camels with Good quality of semen diluted with LYC extender was significantly $(\mathrm{P}<0.05)$ lower than Normal and Poor quality of semen during storage at $5^{\circ} \mathrm{C}$ (Tables 9 and 10). These findings may be explained by the amplified antioxidant enzymes activity, consequently the ability of seminal plasma to reduce the oxidative stress was significantly higher with Good quality of semen than Poor quality of semen. In addition, the enzymatic activity in seminal plasma are good indicator of semen quality because it measure sperm membrane stability (Corteel, 1980). Furthermore, many studies have correlated with AST enzyme level in semen and sperm concentration (Khokhar et al., 1987). Al-Daraji et al. (2002) confirmed that cell membrane was damaged AST and ALT enzymes released into the extracellular sperm medium. Graham and Pace (1967) found that AST and ALT enzymes released into the extracellular medium may reflect the incubation breakdown of the celluar sperm membrane during storage of semen.

It is of interest to note that the advancement of storage time at $5^{\circ} \mathrm{C}$ for 3 days increased significantly $(\mathrm{P}<0.05)$ the amount of AST and ALT enzymes released into the extracellular medium in the all semen qualities (Tables 9 and 10). It appears that sperm damage during storage may be associated with leakage of intracellular enzymes and increased sperm membrane permeability.

Table 9 : Activity of aspartate-aminotransaminase enzyme $\left(U^{\prime 10}{ }^{6}\right.$ spermatozoa) of different semen qualities in the dromedary camel during storage at $5^{\circ} \mathrm{C}$ for 3 days (Means \pm SE).

\begin{tabular}{|c|c|c|c|c|}
\hline \multirow{2}{*}{$\begin{array}{l}\text { Storage time } \\
\text { (days) }\end{array}$} & \multicolumn{3}{|c|}{ Semen quality } & \multirow[t]{2}{*}{ Mean } \\
\hline & Poor & Normal & Good & \\
\hline 0 & $67.18 \pm 1.28$ & $49.84 \pm 0.91$ & $43.72 \pm 0.74$ & $53.58 \pm 1.10^{d}$ \\
\hline $\mathbf{1}$ & $73.63 \pm 1.39$ & $55.13 \pm 1.10$ & $48.57 \pm 0.86$ & $59.11 \pm 1.23^{c}$ \\
\hline 2 & $84.11 \pm 2.06$ & $63.72 \pm 1.23$ & $54.16 \pm 1.12$ & $67.33 \pm 1.30^{a}$ \\
\hline 3 & 92.43.2.13 & $74.50 \pm 1.42$ & $62.25 \pm 1.20$ & $76.39 \pm 1.31^{\mathrm{a}}$ \\
\hline Overall mean & $79.33 \pm 1.98^{\mathrm{A}}$ & $60.89 \pm 1.18^{B}$ & $52.17 \pm 1.08^{\mathrm{C}}$ & 64.10 \\
\hline
\end{tabular}

$\mathrm{A}-\mathrm{C}$ Values with different superscripts within a row are significantly different $(\mathrm{P}<0.05)$. a-d Values with different superscripts within a column are significantly different $(\mathrm{P}<0.05)$. 
Table 10 : Activity of alanine-aminotransaminase enzyme (U/10 ${ }^{6}$ spermatozoa) of different semen qualities in the dromedary camel during storage at $5^{\circ} \mathrm{C}$ for 3 days (Means \pm SE).

\begin{tabular}{|c|c|c|c|c|}
\hline \multirow{2}{*}{$\begin{array}{c}\text { Storage time } \\
\text { (days) }\end{array}$} & \multicolumn{3}{|c|}{ Semen quality } & \multirow[t]{2}{*}{ Mean } \\
\hline & Poor & Normal & Good & \\
\hline 0 & $53.02 \pm 0.83$ & $30.15 \pm 0.38$ & $25.34 \pm 0.34$ & $36.17 \pm 0.61^{d}$ \\
\hline 1 & $58.19 \pm 0.96$ & $35.24 \pm 0.48$ & $29.50 \pm 0.36$ & $40.97 \pm 0.76^{c}$ \\
\hline 2 & $69.14 \pm 1.14$ & $42.73 \pm 0.51$ & $34.27 \pm 0.45$ & $48.71 \pm 1.13^{b}$ \\
\hline 3 & $85.93 \pm 1.98$ & $55.16 \pm 1.13$ & $42.65 \pm 0.78$ & $61.24 \pm 1.18^{a}$ \\
\hline Overall mean & $66.57 \pm 1.27^{\mathrm{A}}$ & $40.82 \pm 0.75^{B}$ & $32.94 \pm 0.42^{\mathrm{C}}$ & 46.77 \\
\hline
\end{tabular}

A-C Values with different superscripts within a row are significantly different $(\mathrm{P}<0.05)$. a-d Values with different superscripts within a column are significantly different $(\mathrm{P}<0.05)$.

\section{Fertility rate $(\%)$ :}

Conception rates of she-camels artificially inseminated with Poor, Normal and Good quality of semen during the first day of storage at $5{ }^{\circ} \mathrm{C}$ were $11.76,61.11$ and $83.33 \%$, respectively with significantly $(\mathrm{P}<0.05)$ different (Table 11) Fertility rates were significantly $(\mathrm{P}<0.05)$ better in the camels having Good quality than Normal or Poor quality of semen which may due to high semen characteristics. Similar trends were reported by Zhang et al. (2001) in bull spermatozoa .

Non of the available literature studied on the effects of semen quality of the dromedary camels on fertility rates, during storage at $5^{\circ} \mathrm{C}$.

Table 11 : Conception rates $(\%)$ in the dromedary she-camels artificially inseminated with different cooled camel semen qualities.

\begin{tabular}{|c|c|c|c|}
\hline Semen quality & $\begin{array}{c}\text { No. of she-camel } \\
\text { inseminated }\end{array}$ & $\begin{array}{c}\text { No. of she-camel } \\
\text { conceived }\end{array}$ & Conception rate (\%) \\
\hline Poor & 17 & 2 & $\mathbf{1 1 . 7 6}^{\mathrm{C}}$ \\
\hline Normal & 18 & 11 & $\mathbf{6 1 . 1 1}^{\mathrm{B}}$ \\
\hline Good & 18 & 15 & $\mathbf{8 3 . 3 3}^{\mathrm{A}}$ \\
\hline
\end{tabular}

a-c : Within a column, within semen quality, means with different superscripts letters differ significantly $(\mathrm{P}<0.05)$.

In conclusion, copulation time, semen characteristics, blood constituents, sperm DNA fragmentation Index were better in the camels with Good quality of semen. In addition, sperm survivability and fertility rates in the camels having Good quality of semen were significantly better with Good quality than Normal and Poor quality of semen stored at $5^{\circ} \mathrm{C}$.

\section{REFERENCES}

Abd El-Raouf, M.F.; M.R. Fatah El-Bab and M.M. Owaida, (1975). Studies on reproduction in the camel (Camelus dromedaries). V. Morphology of the testes in relation to age and season. J. Reprod. Fertile., 43: 109116.

Abraham, G.E. (1977). Handbook of Radioimmunoassay. Macel Dekker, Amsterdam, Holland, 5: 591-656. 
Al-Daraji, H.J.; B.T.O.Al-Tikriti and A.A. Al-Rawi (2002). Study of the trails of endigenous roostert reard during summer months. Iraqian J. of Agric Sci., 33: 223-278.

Amin, Alia S.A.; Abdoun, K.A. and Abdelatif, A.M. (2007). Seasonal variation in blood constituents of one-humped camel (Camelus dromedarius). Pakistan J. Biol. Sci., 10: 1250-1256.

Anouassi, A.; A. Tibary; M. Adnani and A. Sghiri (1994). Preovulatory phase characterization in Camelus dromedarius and induction of ovulation. Proc. of Comp. Organized by FIS in Niamy, Niger, pp. 159-167.

Baiee, F.H. ; H. Wahid ; Y. Rosnina ; O.M. Ariff ; N. Yimer ; H. Salman ; A.A. Tarig and A.M. Khumran (2017). Hypo-osmotic swelling test modification to enhance cell membrane integrity evaluation in cryopreserved bull semen. Pakistan J. Tropical Agric. Sci., 40 (2): 257-268.

Banaszewska, D.; S. Kondracki and A. Wysokinska (2011). Effect of age on the dimensions and shape of spermatozoa of Large White Polish boars. Arch. Tierz, 54 (5): 504-514.

Banerjee, G.C. (1988). "Feeds and Principles of Animal Nutritions". Mohan Primalani of Oxford and IBH Publisthing Co. 66. Janpath New Delhi, India.

Bedrak, E.; Rosenstrauch, A.; Kafka, M. and Friedlander, M. (1983). Testicular steriodogenesis in the camel (Camelus dromedarius) during the mating and the non-mating season. Gen. Comp. Endocrinol., 52: 255-271.

Bravo, P.W.; J.A. Skidmore and X.X. Zhao (2000). Reproductive aspects and storage of semen in camelidae. Anim. Reprod. Sci., 62: 173-193.

Campbell, R.C.; H.M. Dott and T.D. Glover (1956). Nigrosin-Eosin as stain for differentiating live and dead spermatozoa. J. Agric Sci., 48: 1-8.

Chenoweth, P.J. (2005). Genetic sperm defects. Theriogenology, 64:457-468.

Corteel, J.M. (1980). Effects of seminal plasma on survival and fertility of spermatozoa kept in vitro. Reprod. Nutr. Dev., 1111-1123.

Duncan, D.B. (1955). Multiple range and multiple F-test. Biometrics. 11: 1-42.

Enciso, M.H. ; S.D.Cisale ; J. Johnston ; Sarasa J.L. Fernandez and J. Gosalvez (2011). Major morphological sperm abnormalities in the bull are related to sperm DNA damage. Theriogenology, 76: 23-32

Enciso, M. ; C. Lopez-Fernandez ; J.L. Fernandez ; P. Garcia ; A. Goselbez and J.Gosalvez (2006). A new method to analyze boar sperm DNA fragmentation under bright-field or fluoescance microscopy. Theriognology, 65: 308-316.

Erenpreiss, J.; K.Jepson; A.Giwercman; L.Tsarev; J.Erenpreisa and M.Spano (2004). Toluidine blue cytometry test for sperm DNA 
conformation: Comparison with the flow cytometric sperm chromatin structure and TUNEL assys. Hum. Reprod., 19: 2277-2282.

Evenson, D.P. ; K.L. Larson and L.K. Jost (2002). Sperm chro-matin structure assay. Its clinical use for detecting sperm. DNA fragmentation in male infertility and comparisons with other techniques. Intern. J. Andrology, 23: 25-43.

Foote. R.H. and R.W. Bratton (1960). Survival of bovine spermatozoa stored at 5 and $25^{\circ} \mathrm{C}$ in extenders containing varying levels of egg yolk, glucose, glycine. Glycerol, citrate, and other salts. J. Dairy Sci., 43: 1322-1329.

Frenandez, J.L. ; L. Muriel ; M.T. Rivero ; V. Goyanes ; R. Vazquez and J.G. Alvarez (2003). The sperm chromatin dispersion test a simple method for the determiation of sperm DNA fragmentaion. Intern. J. Andrology, 24: 59-66.

Garcia-Macias ;Paulino de Paz Martinez-Pastor ; Alvarez Gomes-Alwes ; Bernardo Enrique Anel and Luis Anel (2007). DNA freagmentation assessment by flow cytometry and Sperm-BosHalomax (bright-field microscopy and fluorescence microsopy) in bull sperm. Intern. J.Andrology, 30: 88-98.

Garnica, J.; R. Achata and P.W.Bravo (1993). Physical and biochemical characteristics of alpaca semen. Anim. Reprod. Sci., 32: 85-90.

Graham, E.F. and M.M. Pace (1967). Some biochemical changes in spermatozoa due to freezing. Cryobiology, 4: 75-81.

Hackett, A.J. and J.W. Macpherson (1965). Some staining procedures for spermatozoa. Canadian Vet. J., 6: 55-62.

Hallap, T. ; S. Nagy ; M. Haard ; U. Jaakma ; A. Johannisson and H. Rodriguez-Martinez (2005). Sperm chromatin stability in frozen thawed semen is maintained over age in $\mathrm{Al}$ bulls. Theriogenology, 63: $1752-1763$.

Jones, R.C. and D.L. Stewart (1979). The effects of cooling to $5{ }^{\circ} \mathrm{C}$ and freezing and thawing on the ultrastructure of bull spermatozoa. J. Reprod. Fertil., 56: 233-238.

Karras, W. (1952). Waermewasserbad und registratur, ihreentwicklung und anwendung Deutschland tieraerzlt-ochenschr. 59. (Suppl. 2) 60-62 and 68-69.

Khan, A.A. (1971). Sexual behaviour of the male camel (Camelus dromedaries) and some studies on semen. MVSc. Thesis, Bikaner Univ. Undaipur, India.

Khan, A.A. and I.S. Kohli (1973). A note on variations in blood serum cholesterol in camel (Camelus dromedarius) before and during rut. Indian J. Anim. Sci., 43:1094-1095.

Khokhar, B.S.; M.Singh and K.C. Chaudhary (1987). Transaminase in Cattle and buffalso semen in relation to fertility and seminal 
characteristics during moderate and colder seasons. Anim. Reprod. Sci., 13: 177-182.

Kondracki, S. ; A. Wysokinska ; M.Iwanina ; D.Banaszewska and D. Sitarz (2011). Effect of sperm concentration in an ejaculate on morphometric traits of spermatozoa in Duroc boars. Polish. J. Vet. Sci., 14 (1): 35-40.

Lioyd, R.E.; Fazeli, A.; Watson, P.E. and Holt, W.V. (2012). The oviductal protein, heat-shock 70 -kDa protein 8 , improves the longterm survival of ram spermatozoa during storage at $17{ }^{\circ} \mathrm{C}$ in a commercial extender. Reprod. Fertil. Dev., 24: 543 - 549.

Mann, T. and C. Lutwak-Mann (1981). Male Reproductive Function and Semen. Springer-Verlag. Berlin, Heidelberg, New York, USA, pp. 264-268.

Matter, M.A.S. (2019). Reproductive and physiological studies on the male dromedary camels during breeding and non-breeding seasons under Egyptian condition. MSc. Thesis, Fac. Agric., Al-Azhar University, Cairo, Egypt.

Murase, T.; K. Okuda and K. Sato (1990). Assessment of bull fertility using a mucus penetration test and a human chorionic gonadotropin stimulation test. Theriogenology, 34: 801-812.

Musa, B.; H. Sieme; H. Merkt and B.E.D. Hago (1992). Artificial insemination in dromedary camels. Proc. $1^{\text {st }}$ Intern. Camel Cong., Dubai, U.A.E. pp. 179-182.

Reitman, S. and M. Frankle (1957). A colorimetric method for determination of semen oxaloacetic and glutamic pyruvic transaminases. Anim. Clin. Pathol. J., 16: 28-56.

Rodriguez, S. ; V. Goyenes ; E. Segrelles ; M. Blasco ; J. Gosalvez and J.I. Fernandez (2005). Critically short telomeres are associated with sperm DNA fragmentation. Fertil. and Steril., 84: 843-845.

Rodriguez- Martinez, H. (2003). Laboratory semen assessment and prdiction of fertility. Still utopia? Repord in Domestic Anim., 38: 312-318.

Salisbury, G.W.; N.L. Van Demark and J.R. Lodge (1978). Physiology of Reproduction and Artificial Insemination of Cattle. WH Freeman and Company, San Francisco, USA.

SAS (2006). SAS Users Guide: Statistical Analysis System. Inst. Inc. Cary, NC, USA.

Shannon, P. and B. Curson (1972). Toxic effect and action of dead sperm on diluted bovine semen. J. Dairy Sci., 55: 614-620.

Tietz, N.W. (1982). Fundamentals of Clinical Chemistry. Norbert Saunders Company, Philadelphia, USA, pp. 401-421.

Watson, P.F. (1975). Use of a giemsa stain to detect changes in acrosomes of frozen ram spermatozoa. Vet. Rec., 97: 12-15 
Willis, J.W. (1960). The determination of metals in blood serum and tissues by atamic absorption spertrophotometry. Spactroch. Acta, 16: 259-272.

Wilson, R.T. (1984). The camel. Longman, London, pp. 83-101.

Yagil, R. and Z. Etzion (1979). Seasonal changes in hormones and behaviour in male camel. Refauh Vet., 36: 70 (Abstr.).

Yassen, A.M. and M.A. El-Kamash (1970). Storagability of buffalo bull sperm in skim milk extenders. Alexandria, J. Agric. Res., 18: 7-12.

Zeidan, A.E.B. (1999). Effects of age on some reproductive traits of the male one-humped camels (Camelus dromedarius). Zagazig Vet. J., 27: 126133.

Zeidan, A.E.B. (2002). Semen quality, enzymatic activities and penetrating ability of spermatozoa into she-camel cervical mucus as affected by caffeine addition. J. Camel Pract. and Res., 9: 153-161.

Zeidan, A.E.B and Abbas, H.E. (2004). Physiological and biochemical changes in the male dromedary camels during rutting and nonbreeding seasons. Zagazig Vet. J., 32: 37-48.

Zeidan, A.E.B.; M.N. El-Gaafary and F.E. El-Keraby (1998). Effects of new packaging method for frozen-bull semen in pellets form on some biochemical changes and conception rate. Proc. $1^{\text {st }}$ Intern. Conf. Anim. Prod. Health in Semi-Arid Areas, El-Arish, North Sinai, Egypt, pp. 223-234.

Zeidan, A.E.B.; A.A.M. Habeeb ; E.A. Ahmadi; H.A. Amer and M.A. Abd El-Razik (2001). Testicular and physiological changes of the male dromedary camels in relation to different ages and seasons of the year. Proc. 2nd Intern. Conf. Anim. Prod. and Health in Semi-Arid Areas, El-Arish, North Sinai, Egypt., pp. 147-160.

Zhang, B.R.; M. Buhr ; T. Kroetsch and S.P.P. Leibo (2001). Glycine betaine improves survival of fresh bovine spermatozoa. Reprod. Fertil. Dev., 13: 187-192.

$$
\begin{aligned}
& \text { تأثير نوعية السائل المنوي على قدرة الحيوانات المنوية على البقاء حيه وتحطم } \\
& \text { DNA } \\
& \text { علاء زيدان، السيد أبو الفتوح أحمدي ، أحمد عامر، ، طارق مهاي ، أحمد لولي دسوقي. } \\
& \text { معهد بحوث الإنتاج الحيواني - الدقي - الجيزة - مصر. }
\end{aligned}
$$

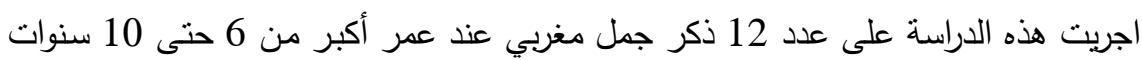

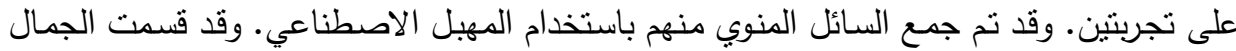

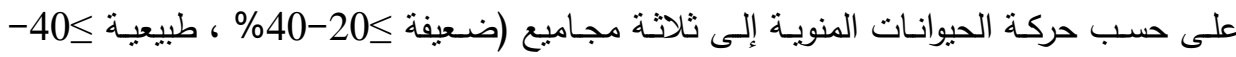

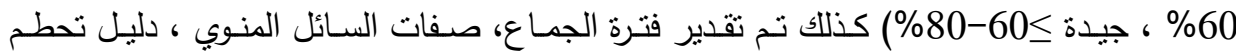

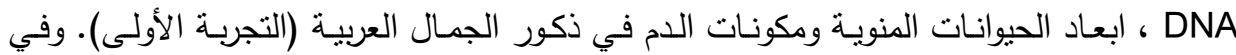

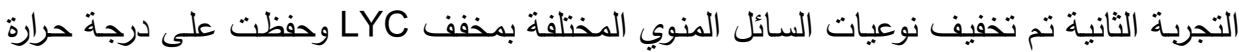


50. لمدة 3 أيام (التجربة الثانية). كذلك تم قياس معدل الاخصـاب (\%) للنوق الملقحة اصطناعيا بنوعيات السائل المنوي المختلفة.

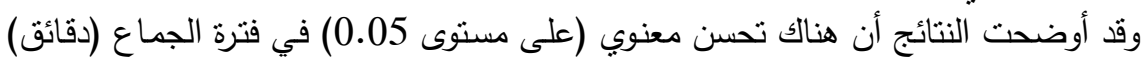

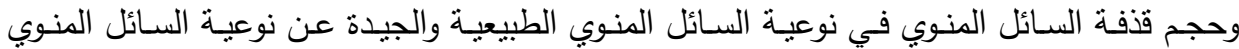

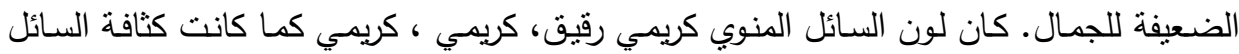

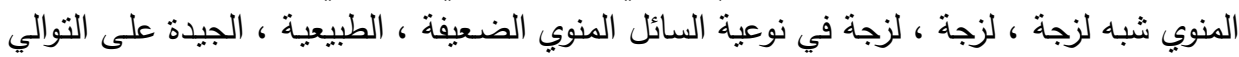

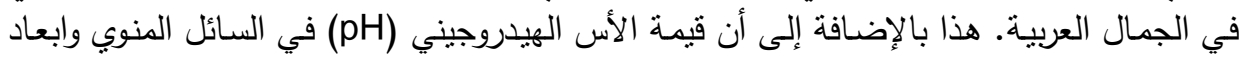

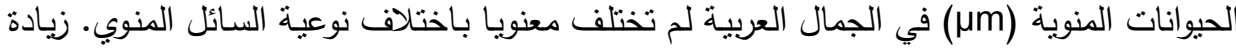

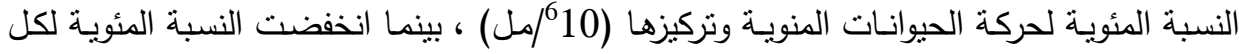

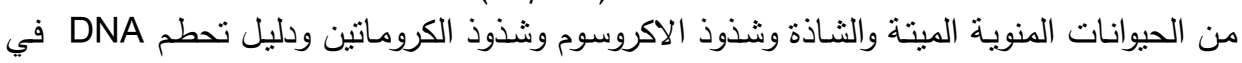

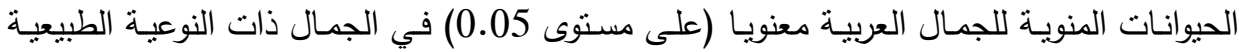

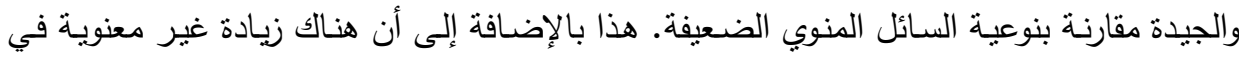

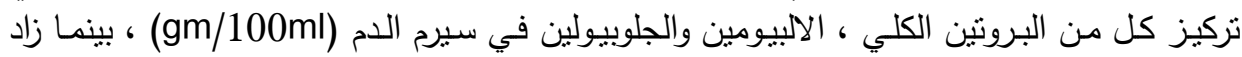

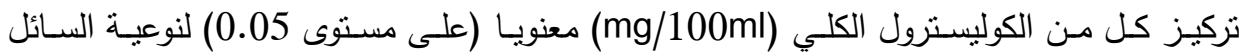

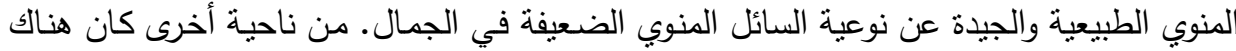

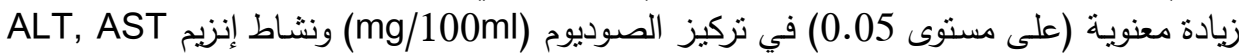

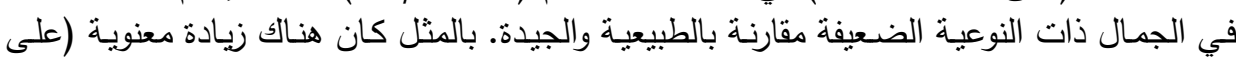

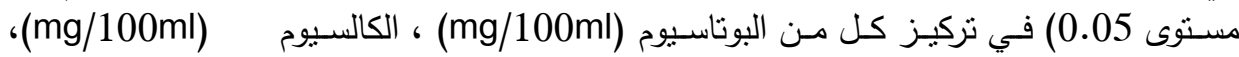
الفوسفور الكلي (mg/100ml) ، الزنـلك (mg/100ml) والتستسترون (ng/100ml) في الجمال

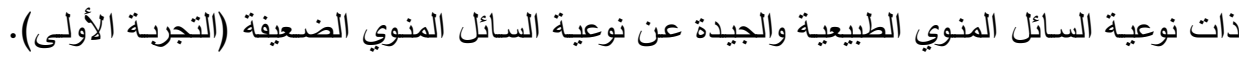

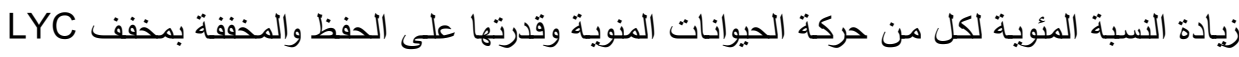

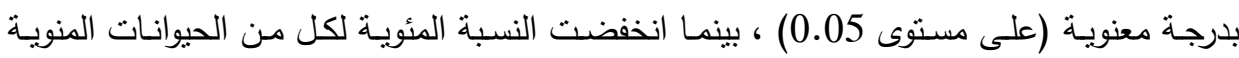

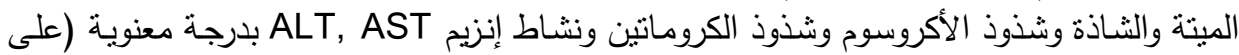

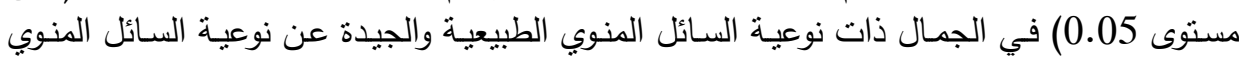

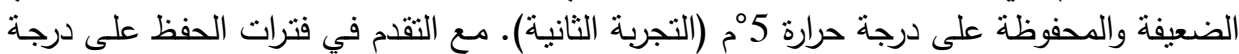

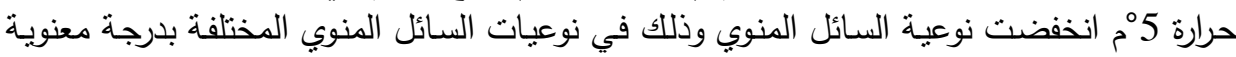

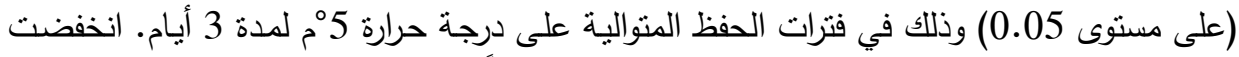

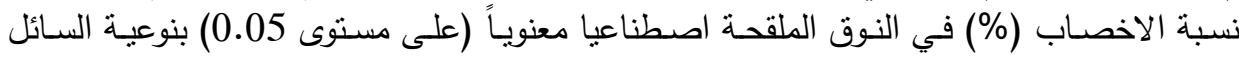
المنوي الضعيفة عن نوعية السائل المنوي الطبيعية والجيدة. 